\title{
PRELIMINARY ASSESSMENT OF HYDROTHERMAL RISKS IN THE EUPHRATES-TIGRIS BASIN: DROUGHTS IN IRAQ
}

\author{
(C) 2018 A.S. Alhumaima, S.M. Abdullaev \\ South Ural State University \\ (pr. Lenina 76, Chelyabinsk, 454080 Russia) \\ E-mail: engineer_alisubhi@yahoo.com,abdullaevsm@susu.ru
}

Received: 27.03.2018

\begin{abstract}
This paper presents a temporal and spatial pattern of precipitation, surface air temperature, and drought occurrence in Euphrates-Tigris rivers basin with special emphases on Iraq. Historical records based on 115 years (1900-2014) of monthly precipitation and temperature data has been divided into four sub-periods, each of 30 years (first 1900-1929, second 1930-1959, third 1960-1989 and fourth 1985-2014) and studied separately. The results showed that the mean annual precipitation in Iraq for the four sub-periods is: 218.5, 202.1, 196.4, and $174.9 \mathrm{~mm}$ respectively, with an average of $198 \mathrm{~mm}$. This indicates that the mean annual precipitation decreased by $43.6 \mathrm{~mm}(20 \%)$ in the fourth sub-period compared to the first sub-period. The mean annual temperature for the four sub-periods in Iraq are $22.0,21.9,22.0,22.8{ }^{\circ} \mathrm{C}$ respectively, with an average of $22.2{ }^{\circ} \mathrm{C}$. This indicates that the average monthly temperature during the year in Iraq increased by $0.76{ }^{\circ} \mathrm{C}(3.45 \%)$ in the fourth subperiod compared to the first sub-period. The probability of occurrence of dry (hot) periods in Iraq increased by $345.5 \%(147.7 \%)$ in the fourth sub-period compared to the first sub-period. Fortunately, the greatest drought occurrence is observed in western parts of Ira, where agriculture is irrigated, in rain-fed areas in the northern Iraq, there has also been a decrease in precipitation, but not so strong as in the west of the country. A preliminary conclusion about the current climatic desertification and its possible consequences for Iraq was drawn.

Keywords: Euphrates-Tigris rivers basin, Iraq, temperature, precipitation, climate change, Standardized Precipitation Index, z-score.
\end{abstract}

\section{FOR CITATION}

Alhumaima A.S. Abdullaev S.M. Preliminary Assessment of Hydrothermal Risks in the Euphrates-Tigris Basin: Droughts in Iraq. Bulletin of the South Ural State University. Series: Computational Mathematics and Software Engineering. 2018. vol. 7, no. 4. pp. 41-58. DOI: $10.14529 / \mathrm{cmse} 180403$.

\section{Introduction}

Climate change is considered to be the biggest challenge the mankind faced in the twenty first century [1]. Climatic change can cause significant impacts on water resources and the hydrological cycle, where the change of the temperature and precipitation will affect the evapotranspiration process. Both, quality and quantity of the runoff component will suffer some changes which will lead to a significant effect on sectors like agriculture, industry and urban development [2]. Also because of climate change and global warming, the increase in air temperature extremes will become more frequent and intense, as well as more widespread during the 21st century [3].

Drought has long been recognized as one of the most insidious causes of human misery and the natural disaster that annually claims most victims. Drought is defined based on the deficiency of precipitation that results in water shortage for activities related to use of water. It begins with the meteorological drought caused by precipitation deficiency. Prolonged meteorological drought can cause an agricultural drought as the precipitation deficit propagates 


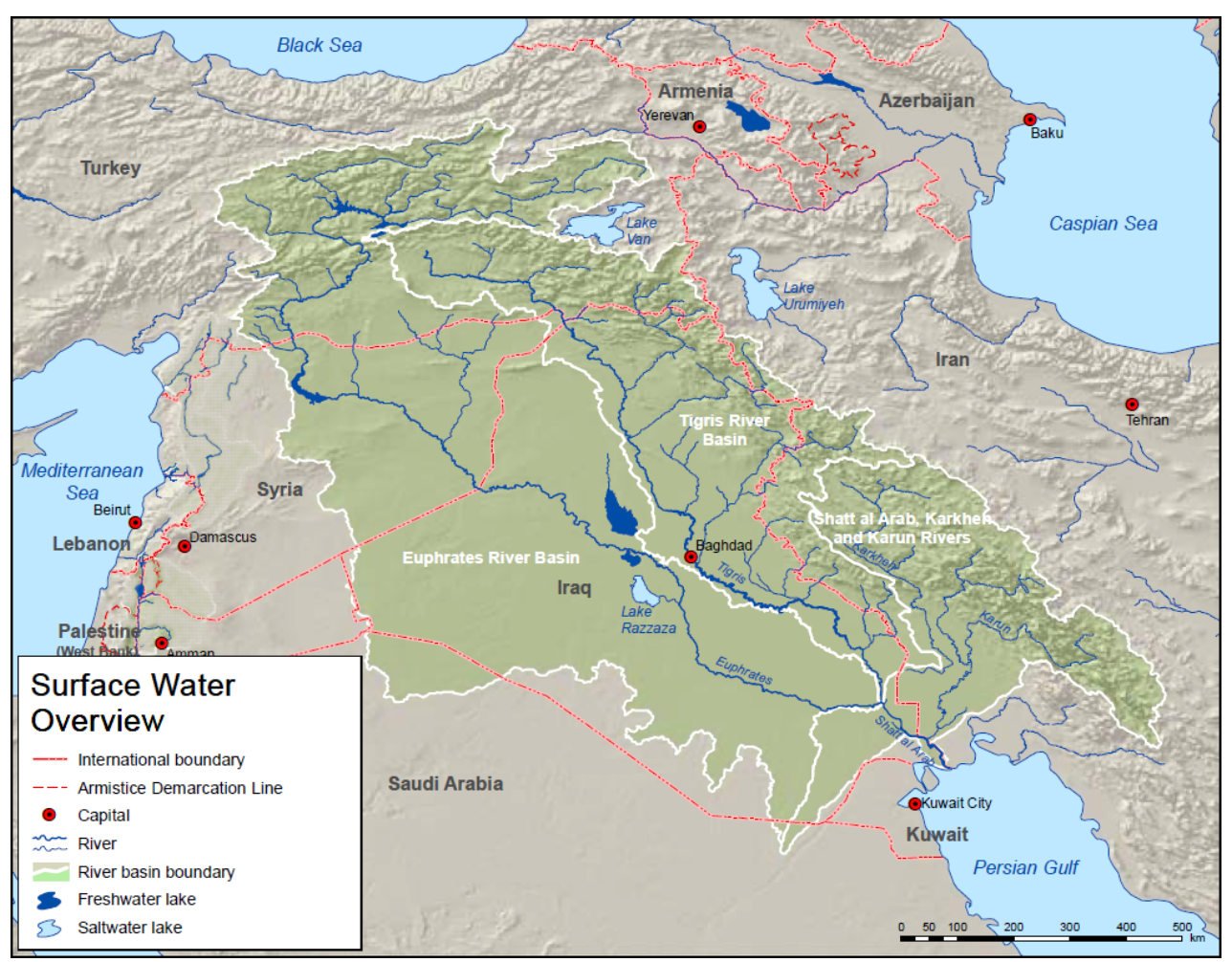

Fig. 1. Overview map of location and shared surface water within Euphrates-Tigris rivers basin

into soil moisture deficit and reduces crop production. Meteorological drought may be followed by hydrological drought, which can affect river flows, levels in lakes, and aquifer recharge [4].

A common tool utilized to monitor current drought conditions is a drought index. Several drought indices can be used to forecast the possible evolution of an ongoing drought, in order to adopt appropriate mitigation measures and drought policies for water resources management. This is because a drought index is expressed by a numeric number, which is believed to be far more functional than raw data during decision-making [5]. Different indices are available globally to quantify drought, each with its own strengths and weaknesses [6]. These include the Palmer Drought Severity Index [7], Standardized Precipitation Index [8], Standardized Precipitation Evapotranspiration Index [9], Effective Drought Index [10], and many others. In this paper, the standardized precipitation index (SPI), proposed by McKee et al. [8] is used to analyze the characteristics of drought. There are a number of strengths to the SPI approach: (i) it only uses one relatively commonly available parameter (i.e. precipitation); (ii) it can be estimated for a variety of timescales (by calculating using precipitation data for a range of accumulation periods); (iii) it is relatively simple compared with other widely used indices such as the Palmer Drought Severity Index (PDSI); and (iv) it is spatially constant, again unlike the PDSI [11]. Since SPI is standardized and has a probabilistic interpretation, it can be used in risk assessment and decision-making [6].

Extreme heat events are among the most serious challenges for society coping with a changing climate and can be very harmful to human health, ecosystems, agriculture and economic sectors such as energy generation and tourism [3]. One of the popular tools used for analyzing the temperature time series datasets is the statistical z-score technique [3, 12]. 
The economic life of the Euphrates-Tigris Basin remains reliant on the rivers' waters. Historically, the agriculture of southeastern Anatolia, as well as of northern Iraq and Syria, has been entirely dependent on rainfall, with some minor mechanical irrigation systems particularly in Syria [13]. Iraq is one of the riparian countries within the Euphrates-Tigris Rivers basin in the Middle East region (Fig. 1 [14]); the region is currently facing water shortage problems due to the increase of the demand and climate changes [15].

As the country furthest downstream in the basin, Iraq is heavily dependent on precipitation in the highlands of Turkey and Iran. The population of Iraq in the 1980s was approximately 13.7 million people, and increased to 31 million in 2010s; and it is expected that the population will keep on increasing to reach 71.3 million in 2050 (the rate is about $3.6 \%$ ) [16]. According to the Ministry of Planning/ Central Statistical Organization/ Annual Statistical Abstract 2014-2016 [17], the total population of Iraq is about 36.004 million in 2014, and with the $437,065 \mathrm{~km}^{2}$ total land area of Iraq, the population density is about 82.73 inhabitants $/ \mathrm{km}^{2}$. Although the contribution of agriculture to the overall Iraqi gross domestic product (GDP) is below 5 percent, one-third of people resides in rural areas and depends on agriculture for their livelihoods. After the public service and trade sectors, agriculture is the third largest provider of employment in the country, and the largest source of employment for the rural population [18].

According to the Ministry of Agriculture, "Annual Agricultural Statistical Data (2014)", Arable Area in Iraq represents $34 \%$ of the total area of Iraq [19]. The republic of Iraq consists of 18 muqhaphas: Al-Anbar, Babil, Baghdad, Basra, Dhi-Qar, Al-Diwaniyah, Diyala, Dohuk, Erbil, Karbala, Kirkuk, Maysan, Muthanna, Najaf, Nineveh, Saladin, Sulaymaniyah, and Wasit. Within the agriculture sector, crop production constitutes the largest subsector and provides 75 percent of agricultural income. Crop production such as grains, primarily wheat and barley, are Iraq's main crops in the north and central rain fed areas (Kirkuk, Saladin, and Sulaymaniyah). The rain fed land in the northern part of the country is highly responsive to variations in the timing and quantity of precipitation [18].

In central and southern (Baghdad, Al-Diwaniyah, Diyala and others) areas, where agriculture is mainly irrigated by the Tigris and Euphrates, mixed farming systems (rice, wheat and barley) are predominant, and vegetables, mainly tomatoes and potatoes, are important, also. Crop production from irrigated land in Iraq is very sensitive to any change in the seasonal availability of water resources from the two main rivers Euphrates and Tigris. Dates are a major cash and food crop with fruit trees inter-planted in date palm orchards in southern Iraq. Meanwhile, livestock is the second largest subsector with 13.5 million heads of cattle, goats, and sheep, and 14 million of poultry, as of 2013 [18].

There have been many studies to assess hydrothermal risks around the world, but very few in Iraq. However, in [20] the frequency of drought for the period 1980 to 2010 in Iraq was investigated, based on monthly rainfall data collected from 39 meteorological stations distributed across the country, in [4] the standardized precipitation index (SPI) at different time scales, i.e., 3, 6, 12, and 24-month, were used to analyze the meteorological drought for the period 1937-2010 in northern Iraq, in [2] the historical records of the average monthly temperature and rainfall for the period of 1900-2009 for the Middle East and North Africa countries with special emphases on Iraq were studied, in [21] the trends of temperature for the period of 1941-2000 for Baghdad, Iraq were investigated, in [22] ten average climate indices (total rainfall, average temperature, maximum temperature, minimum temperature, number 
of days of dust rising, number of days of dust storm, relative humidity, atmospheric pressure at sea surface level, total evaporation and wind speed) were investigated at 24 meteorological stations in Iraq for 30 years, and finally in [23] the SPI at 9, 12-month time scales was used to study and analyze drought characteristics in Iraq dependent on the observed climate data from 10 meteorological stations during 1980-2011.

In this paper, the historical time series of the average monthly temperature and precipitation for the period of 1900-2014 (115 years) for the Euphrates-Tigris rivers basin was divided into four sub-periods of thirty years and investigated separately. Understanding and predicting the trends of hydrothermal risks including drought risks, heavy precipitation events, and periods of extremely high and low temperature in Iraq and using this knowledge could be helpful to support hydrothermal risks management and develop effective mitigation strategies. This paper aims to provide a comprehensive analysis of hydrothermal risks in the Euphrates-Tigris rivers basin with a special emphasis on Iraq as follows: (1) analysis of the spatial and temporal variation of precipitation; (2) analysis of the spatial and temporal variation of surface air temperature; and (3) analysis of the spatial and temporal variation of the 12-month hydrological SPI drought index and the temperature standardized z-score.

The paper is organized as follows: this Section examines the underlying concepts of drought impacts, the available indices to quantify drought and the previous works in literature; Section 1 gives a brief overview of the study area and describes the datasets and methods used; in Section 2, the spatial and temporal variation of precipitation, surface air temperature, and hydrological drought in the Euphrates-Tigris rivers basin were analyzed and discussed. Finally, the study is concluded in the last Section.

\section{Region, data and methods}

The Euphrates-Tigris River Basin is a transboundary basin (see Fig. 1 [12]) with a total area of $879,790 \mathrm{~km}^{2}$ (13\% of Middle East) distributed mainly (98\%) between Iraq, Turkey, the Islamic Republic of Iran, the Syrian Arab Republic (Tab. 1, [24]). Iraq lies at $33^{\circ}$ North latitude and $44^{\circ}$ East longitude. The north south extents of Iraq's borders run from $37^{\circ} 21^{\prime} \mathrm{N}$ in the north region along its northern border with Turkey to $29^{\circ} 04^{\prime} \mathrm{N}$ along its southern border with Saudi Arabia. Iraq's east-west extent spans from $38^{\circ} 56^{\prime}$ in the Syrian Desert to $48^{\circ} 36^{\prime}$ in the vicinity of the Shatt al Arab [16].

Table 1

Country areas in the Euphrates-Tigris River Basin

\begin{tabular}{|c|c|c|c|}
\hline $\begin{array}{c}\text { Basin and countries } \\
\text { included }\end{array}$ & $\begin{array}{c}\text { Basin per country } \\
\left(\mathrm{Km}^{2}\right)\end{array}$ & $\begin{array}{c}\text { \% of total area of } \\
\text { the basin }\end{array}$ & $\begin{array}{c}\text { \% of total area of } \\
\text { the country }\end{array}$ \\
\hline Euphrates-Tigris & 879790 & 100 & - \\
\hline Iraq & 407880 & 46.4 & 93.1 \\
\hline Turkey & 129190 & 21.8 & 24.5 \\
\hline Iran & 166240 & 18.9 & 9.5 \\
\hline Syria & 96420 & 11.0 & 52.1 \\
\hline Saudi Arabia & 16840 & 1.9 & 0.8 \\
\hline Jordan & 220 & 0.03 & 0.2 \\
\hline
\end{tabular}


The Euphrates and Tigris Rivers originate from the highlands of eastern Turkey, Iran, and Syria, and discharge south into Syria and Iraq, where they merge to feed the Mesopotamian marshlands in southern Iraq. Nearly all of the flow $(90 \%)$ of the Euphrates River originates in the highlands of eastern Turkey, with modest contributions from the Syrian highlands but only minimal additions from Iraq. The mountains in eastern Turkey contribute a smaller amount $(40 \%)$ to the Tigris river flow, and the remainder comes from numerous tributaries that originate in the Zagros Mountains between Iraq and Iran [25]. The Tigris and Euphrates Rivers are the most important surface water resources for Turkey, Syria and Iraq. They are also important to life, socioeconomic development, and political stability in the Middle East [26].

The upper basin of the rivers is characterized by the rock and mountain gorges of Anatolia and the high plateaus of Syria and Iraq. The climate of the catchment area may be regarded as being similar to a Mediterranean climate except some differences due to the presence of a mountainous region which is located within the Turkish territory. The climate is a hot-dry summer and cold-rainy winter with occasional snowfall taking place in the mountain region. The precipitation in Mesopotamian basin occurs between October and May. The annual precipitation over the Euphrates-Tigris Rivers basin ranges between 100 and $1000 \mathrm{~mm}$ $[15,27]$. The heaviest precipitation occurs from December to February. Generally, snow melting begins in February causing higher discharges during spring flows (March to May or early June). Low water discharges are usually during the hotter and drier summer months (July to October). During this period the main source of the rivers runoff is groundwater. The average monthly temperatures range from $6{ }^{\circ} \mathrm{C}$ in January to $34{ }^{\circ} \mathrm{C}$ in July, but the temperatures decrease towards the north $[15,27,28]$.

\subsection{Dataset and calculations}

The datasets used in this paper which are the observations of monthly mean surface air temperatures (at $2 \mathrm{~m}$ above surface) and monthly total precipitation are obtained from the University of Delaware Air Temperature dataset (Version 4.01) [29], which provides monthly global gridded high resolution station (land) data from the period 1900-2014. A large number of stations from the Global Historical Climate Network (GHCN) and various other sources are used in the production of this dataset [30]. All the results presented in this paper were calculated using MATLAB programming language version 8.5.0.197613 (R2015a), whereas the ArcGIS version 10.1 was used to simulate the results as geographical maps. The Euphrates-Tigris rivers basin shapefile used within the ArcGIS was projected using the map of the area presented in Fig. 1. The whole period covered 115 years (1900-2014), was divided into four sub-periods, each of 30 years as follows: first 1900-1929, second 1930-1959, third 19601989 and fourth 1985-2014. We mainly produced simple calculations of the mean values of temperature and precipitation for the sub-period and evaluated the difference between these values with the average for 115 years. The probability of occurrence of various categories of hot and cold months was defined as a month in which its absolute value of the standardized monthly mean temperature value exceeds 0.99 ( $\mid$ z-score $\mid>0.99$ ), as follows: $0.99 \leq \mid z$-score $\mid \leq$ 1.49 for moderate, $1.5 \leq \mid z$-score $\mid \leq 1.99$ for very high, and $\mid z$-score $\mid \geq 1.99$ for extreme, the $z$ score is calculated as follows:

$$
Z=\frac{\left(T-T_{\text {mean }}\right)}{\sigma},
$$


where $T_{\text {mean }}$ and $\sigma$ are the mean and standard deviation of the monthly time series temperature.

More complex calculations were needed in the calculation of Standardized Precipitation Index (SPI). The SPI [8] is widely used around the world for drought forecasting, frequency analysis, spatial-temporal analysis and climate impact studies. SPI is also recommended as a meteorological drought index by the World Meteorological Organization [6]. The computation of the SPI drought index for any location is based on the long-term precipitation record (at least 30 years) cumulated over a selected time scale. This long-term precipitation time series is then fitted to a gamma distribution, which is then transformed through an equal probability transformation into a normal distribution. Positive (negative) SPI values indicate wet (dry) conditions with greater (lower) than median precipitation [5].

In most cases, the probability distribution that best models observational precipitation data is the Gamma distribution. The gamma distribution is defined by its frequency or probability density function $[5,31]$ :

$$
g(x)=\frac{1}{\beta^{\alpha} \Gamma(\alpha)} x^{\alpha-1} e^{-x / \beta}, \text { for } x>0,
$$

where $\alpha>0$ is the shape parameter, $\beta>0$ is the scale parameter, and $\mathrm{x}>0$ is the amount of precipitation. $\Gamma(\alpha)$ is the Gamma function, which is defined by the integral:

$$
\Gamma(\alpha)=\int_{0}^{\alpha} \gamma^{\alpha-1} e^{-\gamma} d \gamma
$$

Computation of the SPI involves fitting a gamma probability density function to a given frequency distribution of precipitation total for a station. The maximum likelihood solutions are used to optimally estimate $\alpha$ and $\beta$ for n precipitation observations:

$$
\alpha=\frac{1}{4 A}\left(1+\sqrt{1+\frac{4 A}{3}}\right) ; \quad \text { where } A=\ln (\bar{x})-\frac{\sum \ln (x)}{n} \text { and } \beta=\frac{\bar{x}}{\alpha}
$$

The cumulative probability $\mathrm{G}(\mathrm{x})$ is given by:

$$
G(x)=\int_{0}^{x} g(x) d x=\frac{1}{\beta \Gamma(\alpha)}=\int_{0}^{x} x^{\alpha-1} e^{-x / \beta} d x
$$

The Gamma function is not defined by $\mathrm{x}=0$, and since there may be no precipitation, the cumulative probability becomes:

$$
H(x)=q+(1-q) G(x)
$$

Where $q$ is the probability of no precipitation. $\mathrm{H}(\mathrm{x})$ is the cumulative probability of precipitation observed. The cumulative probability is then transformed to the standard normal random variable $\mathrm{Z}$ with mean zero and variance of one, which is the value of the SPI. SPI is categorized based on their range values, is shown in Tab. 2.

Table 2

Drought classification based on SPI

\begin{tabular}{|c|c|c|c|}
\hline SPI values & Class & SPI values & Class \\
\hline 2.00 and more & Extremely wet & -2.00 and less & Extremely dry \\
\hline 1.50 to 1.99 & Very wet & -1.50 to -1.99 & Very dry \\
\hline 1.00 to 1.49 & Moderately wet & -1.00 to -1.49 & Moderately dry \\
\hline 0.99 to 0.00 & Normal & 0.00 to -0.99 & Near normal \\
\hline
\end{tabular}




\section{Results and discussion}

\subsection{Spatial and temporal analysis of regional precipitation}

There is a large spatial variation in precipitation amount over the Euphrates-Tigris rivers (ET) basin. Fig. 2 (a) illustrates the spatial variation of the precipitation anomalies for the first sub-period compared to the average of the whole period from 1900 to 2014, positive precipitation anomalies (up to $143.6 \mathrm{~mm}$ above normal) dominate $87.4 \%$ of the area within the ET basin, whereas negative precipitation anomalies (down to $37.5 \mathrm{~mm}$ below normal) dominate $12.6 \%$ of the region, with a mean of $19.15 \mathrm{~mm}$ and standard deviation of $27.0 \mathrm{~mm}$.

Fig. 2 (b) illustrates the spatial variation of the precipitation anomalies for the second sub-period, positive precipitation anomalies (up to $38.45 \mathrm{~mm}$ above normal) dominate $73.7 \%$ of the area within the ET basin, whereas negative precipitation anomalies (down to $32.2 \mathrm{~mm}$ below normal) dominate $26.3 \%$ of the region, with a mean of $4 \mathrm{~mm}$ and standard deviation of 10.7. Fig. 2 (c) illustrates the spatial variation of the precipitation anomalies for the third sub-period, positive precipitation anomalies (up to $54.5 \mathrm{~mm}$ above normal) dominate $36.6 \%$

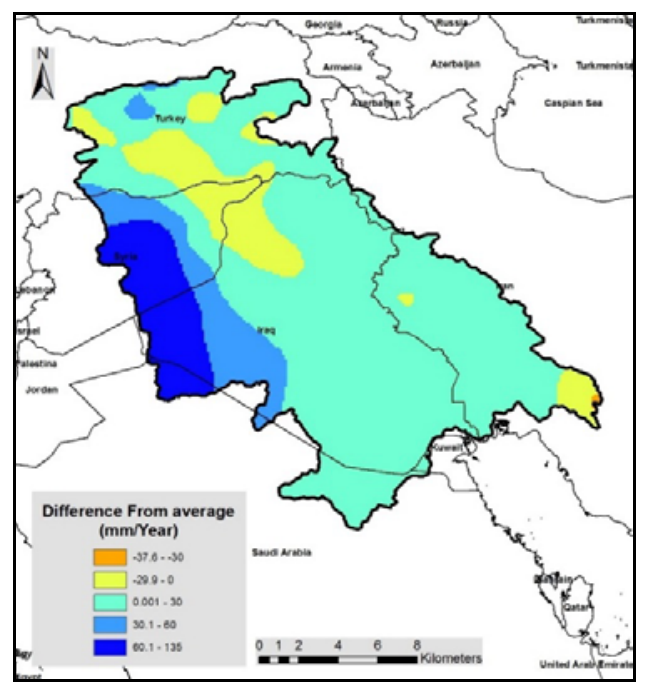

a) $1900-1929$

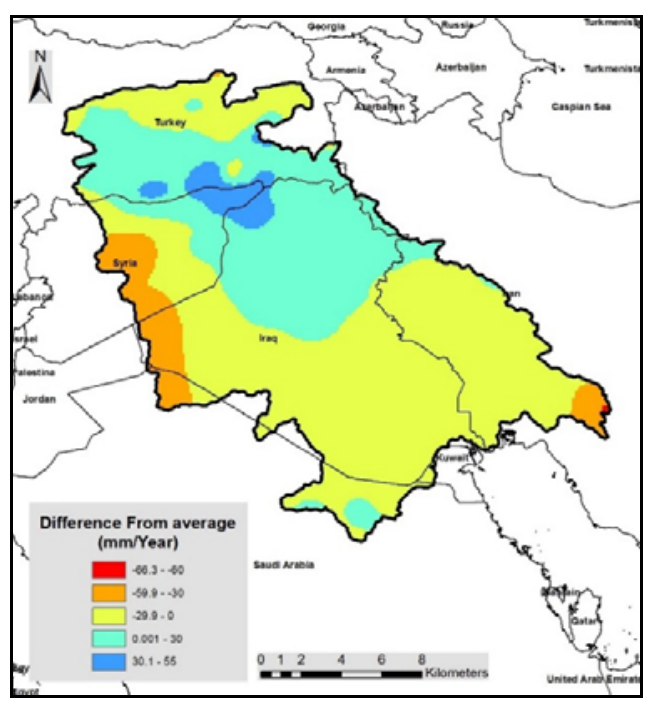

c) $1960-1989$

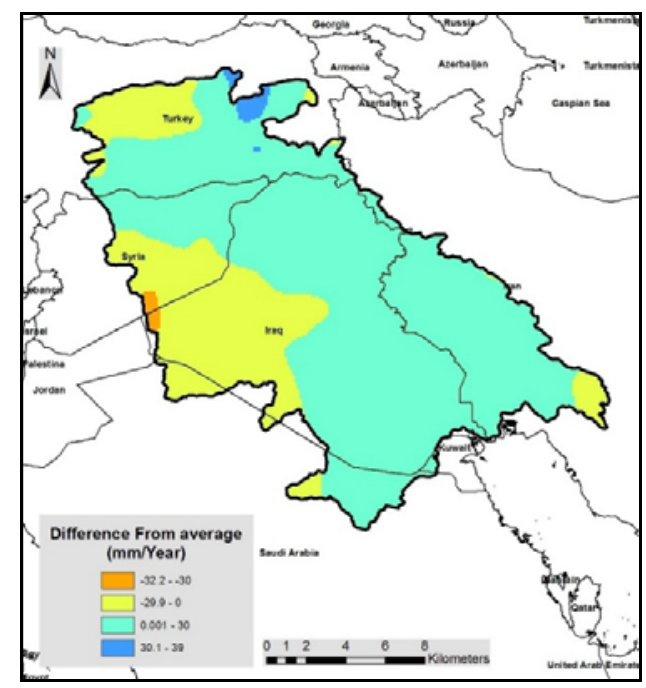

b) $1930-1959$

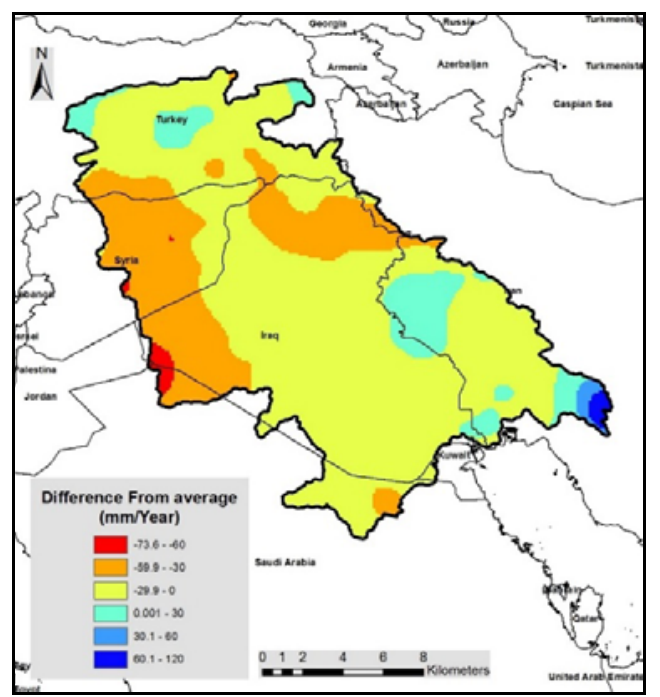

d) $1985-2014$

Fig. 2. Spatial variation of the mean annual precipitation anomalies over 115 years 
Preliminary Assessment of Hydrothermal Risks in the Euphrates-Tigris Basin: Droughts...

of the area within the ET basin, whereas negative precipitation anomalies (down to $66.3 \mathrm{~mm}$ below normal) dominate $63.4 \%$ of the region, with a mean of $-66.3 \mathrm{~mm}$ and standard deviation of $54.5 \mathrm{~mm}$. Finally, Fig. 2 (d) illustrates the spatial variation of the precipitation anomalies for the fourth sub-period. Positive precipitation anomalies (up to $120.2 \mathrm{~mm}$ above normal) dominate only $10 \%$ of the area within the ET basin, whereas negative precipitation anomalies (down to 73.6 below normal) dominate $10 \%$ of the region, with a mean of $19.15 \mathrm{~mm}$ and standard deviation of $18.60 \mathrm{~mm}$.

\subsection{Temperature anomaly in ET basin}

Fig. 3 (a) illustrates the spatial variation of the temperature anomalies for the first sub-period compared to the average of the whole period from 1900 to 2014 . Positive temperature anomalies (up to $0.162{ }^{\circ} \mathrm{C}$ above normal) dominate $8.4 \%$ of the area within the Euphrates- Tigris Rivers basin, whereas negative temperature anomalies (down to $0.51{ }^{\circ} \mathrm{C}$ below normal) dominate $91.6 \%$ of the region, with a mean of $-0.12{ }^{\circ} \mathrm{C}$ and standard deviation of $0.09{ }^{\circ} \mathrm{C}$.

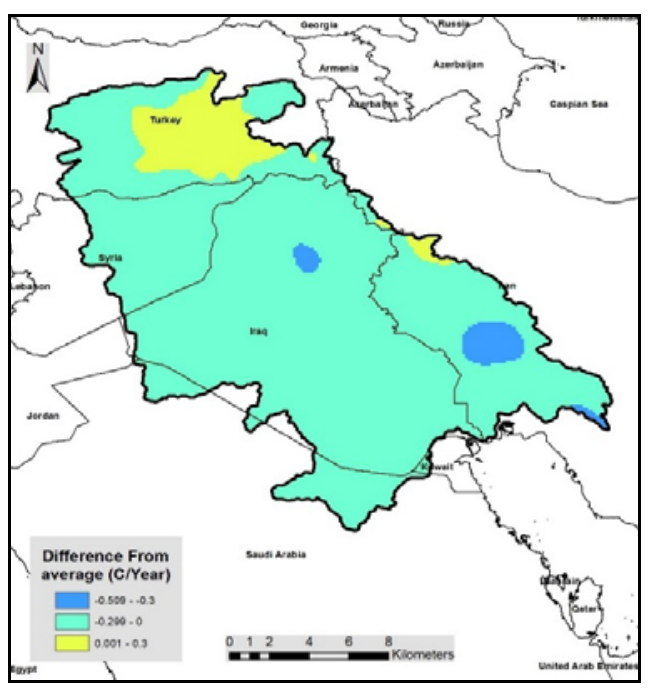

a) $1900-1929$

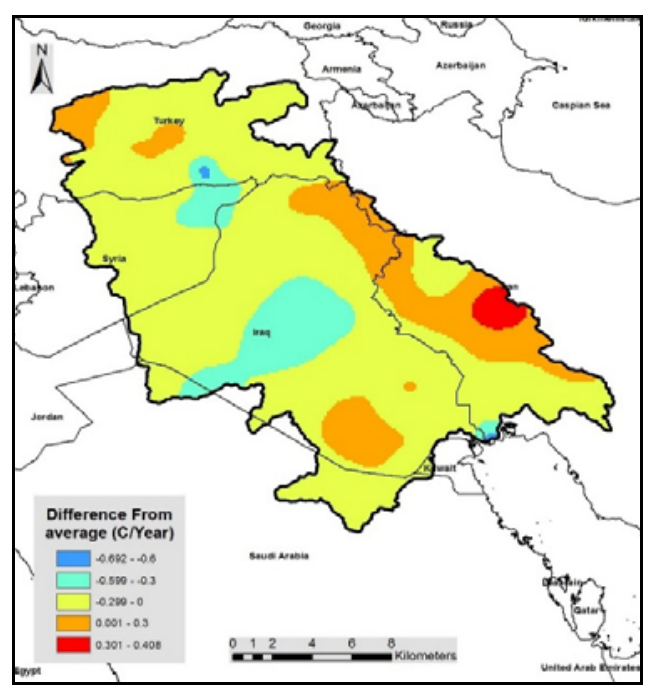

c) $1960-1989$

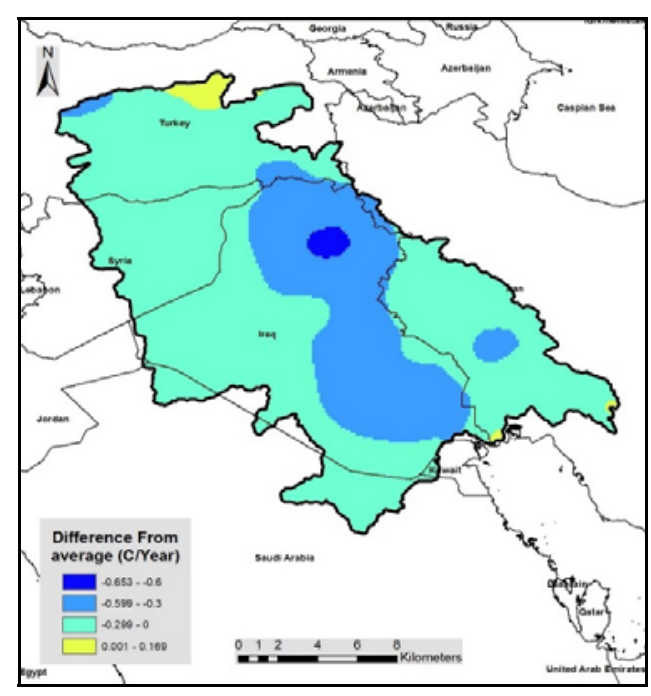

b) $1930-1959$

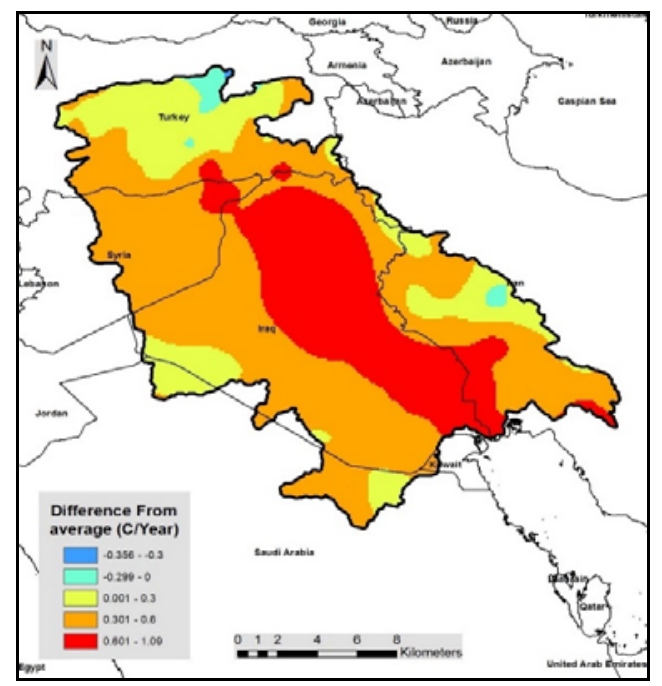

d) $1985-2014$

Fig. 3. Spatial variation of the mean annual temperature anomalies over 115 years 
Fig. 3 (b) illustrates the spatial variation of the temperature anomalies for the second sub-period. Positive temperature anomalies (up to $0.17^{\circ} \mathrm{C}$ above normal) dominate $1.52 \%$ of the area within the Euphrates-Tigris Rivers basin, whereas negative temperature anomalies (down to $0.65{ }^{\circ} \mathrm{C}$ below normal) dominate $98.5 \%$ of the region, with a mean of $-0.24{ }^{\circ} \mathrm{C}$ and standard deviation of 0.13 . Fig. 3 (c) illustrates the spatial variation of the temperature anomalies for the third sub-period. Positive temperature anomalies (up to $0.41{ }^{\circ} \mathrm{C}$ above normal) dominate $18.40 \%$ of the area within the Euphrates-Tigris Rivers basin, whereas negative temperature anomalies (down to $0.69{ }^{\circ} \mathrm{C}$ below normal) dominate $81.60 \%$ of the region, with a mean of $-0.12{ }^{\circ} \mathrm{C}$ and standard deviation of $0.15{ }^{\circ} \mathrm{C}$. Finally, Fig. 3 (d) illustrates the spatial variation of the temperature anomalies for the fourth sub-period. Positive temperature anomalies (up to $1.09{ }^{\circ} \mathrm{C}$ above normal) dominate $98.6 \%$ of the area within the Euphrates-Tigris Rivers basin, whereas negative temperature anomalies (down to $0.355{ }^{\circ} \mathrm{C}$ below normal) dominate $1.4 \%$ of the region, with a mean of $0.46{ }^{\circ} \mathrm{C}$ and standard deviation of $0.216{ }^{\circ} \mathrm{C}$.

\subsection{Precipitation and temperature by country}

Variation in precipitation amount depending on the area of each country located within the basin is demonstrated by Tab. 3 .

Table 3

Change of annual precipitation and temperature in ET basin shared by countries

\begin{tabular}{|c|c|c|c|c|c|c|}
\hline Country & $1900-1929$ & $1930-1959$ & $1960-1989$ & $1985-2014$ & mean & units \\
\hline \multirow{2}{*}{ Turkey } & 595.6 & 594.5 & 595.4 & 573.8 & 589.8 & $\mathrm{~mm}$ \\
\cline { 2 - 7 } & 12.62 & 12.48 & 12.55 & 12.91 & 12.64 & ${ }^{\circ} \mathrm{C}$ \\
\hline \multirow{2}{*}{ Syria } & 270.9 & 220.2 & 213.0 & 181.9 & 212.5 & $\mathrm{~mm}$ \\
\cline { 2 - 7 } & 18.69 & 18.63 & 18.58 & 19.27 & 18.79 & ${ }^{\circ} \mathrm{C}$ \\
\hline \multirow{2}{*}{ Iran } & 341.0 & 341.2 & 321.7 & 333.6 & 334.4 & $\mathrm{~mm}$ \\
\cline { 2 - 8 } & 19.21 & 19.19 & 19.39 & 19.78 & 19.39 & ${ }^{\circ} \mathrm{C}$ \\
\hline \multirow{2}{*}{ Iraq } & 218.5 & 202.1 & 196.4 & 174.9 & 198.0 & $\mathrm{~mm}$ \\
\cline { 2 - 8 } & 22.0 & 21.9 & 22.0 & 22.76 & 22.2 & ${ }^{\circ} \mathrm{C}$ \\
\hline
\end{tabular}

This indicates that the average total precipitation during the year in all countries of basin decreased in the fourth sub-period compared to the first sub-period, and all countries have precipitation in 1985-2014 lower than average. The amount in countries with lower part of basin: Syria and Iraq decreased by $33 \%$ and $20 \%$, and countries of upper part of basin Iran and Turkey decreased by only $2-4 \%$. A large spatial variation in temperature over the Euphrates-Tigris rivers basin was detected, also. This indicates that mean annual temperature in Syria and Iraq increased by $3-3.5 \%$, respectively, in the fourth sub-period compared to the first sub-period. In Turkey and Iran temperature rising is $2.5 \%-3 \%$.

\subsection{Seasonal precipitation and temperature change in Iraq}

Using the average of the whole period $1900-2014$ as a precipitation benchmark for all other sub-periods, Tab. 4 illustrates the mean precipitation anomalies ( $\mathrm{mm}$ ) for rainy months of the four sub-periods in Iraq. What distinguishes the comparison is that the decrease in mean monthly precipitation took place during all rainy months within the fourth sub-period. 
Preliminary Assessment of Hydrothermal Risks in the Euphrates-Tigris Basin: Droughts...

Table 4

Mean of monthly precipitation anomalies $(\mathrm{mm})$ for the four sub-periods in Iraq

\begin{tabular}{|c|c|c|c|c|}
\hline Month & $1900-1929$ & $1930-1959$ & $1960-1990$ & $1985-2014$ \\
\hline Jan & 3.911 & 2.305 & -1.132 & -6.101 \\
\hline Feb & 3.444 & 0.626 & 1.162 & -6.278 \\
\hline Mar & 2.990 & -0.039 & 0.365 & -3.979 \\
\hline Apr & 2.312 & 0.242 & 1.241 & -4.555 \\
\hline Nov & 3.615 & -0.681 & -0.940 & -2.393 \\
\hline Dec & 2.495 & 3.299 & -1.404 & -5.268 \\
\hline
\end{tabular}

The mean monthly temperature over 115 years in Iraq fluctuated between the lowest and highest values of $6.86{ }^{\circ} \mathrm{C}$ during January and $32.17^{\circ} \mathrm{C}$ during July respectively. Using the average of the whole period 1900-2014 as a temperature benchmark for all other sub-periods, Tab. 5 illustrates the mean monthly temperature anomalies for the 12 months of the four sub-periods in Iraq. What distinguishes the comparison of the four sub-periods with the average is that the decrease in mean monthly temperature took place during all months.

Table 5

Mean of monthly temperature anomalies ${ }^{\circ} \mathrm{C}$ for the four sub-periods in Iraq

\begin{tabular}{|c|c|c|c|c|}
\hline Month & $1900-1929$ & $1930-1959$ & $1960-1990$ & $1985-2014$ \\
\hline Jan & -0.136 & -0.205 & -0.042 & 0.459 \\
\hline Feb & -0.316 & -0.296 & 0.119 & 0.592 \\
\hline Mar & -0.264 & -0.481 & 0.054 & 0.829 \\
\hline Apr & -0.301 & -0.292 & -0.137 & 0.876 \\
\hline May & -0.371 & -0.414 & -0.011 & 0.955 \\
\hline Jun & -0.284 & -0.541 & -0.116 & 1.130 \\
\hline Jul & -0.096 & -0.458 & -0.101 & 0.785 \\
\hline Aug & -0.045 & -0.226 & -0.340 & 0.733 \\
\hline Sep & 0.117 & -0.369 & -0.072 & 0.389 \\
\hline Oct & 0.135 & -0.062 & -0.388 & 0.378 \\
\hline Nov & 0.318 & -0.017 & -0.388 & 0.104 \\
\hline Dec & -0.027 & -0.186 & -0.161 & 0.449 \\
\hline
\end{tabular}

\subsection{Analysis of drought index and temperature z-score}

The SPI drought index was calculated at 12-month time scale and analyzed at a regional scale in reference to the mean monthly precipitation in Iraq. Fig. 4 (a) illustrates the spatial variation of the 12-month SPI anomalies for the second sub-period compared to the average of the first sub-period from 1900 to 1929. Positive anomalies up to 0.336 above normal (wet) dominate $38.43 \%$ of the area within the Euphrates-Tigris Rivers basin, whereas negative drought anomalies down to 1.53 below normal (dry) dominate $61.57 \%$ of the region.

Fig. 4 (b) illustrates the spatial variation of the SPI anomalies for the third sub-period. Positive anomalies (up to 0.425 above normal) dominate $21.86 \%$ of the area within the Euphrates-Tigris Rivers basin, whereas negative SPI anomalies (down to 1.804 below normal) 


\section{A.S. Alhumaima, S.M. Abdullaev}

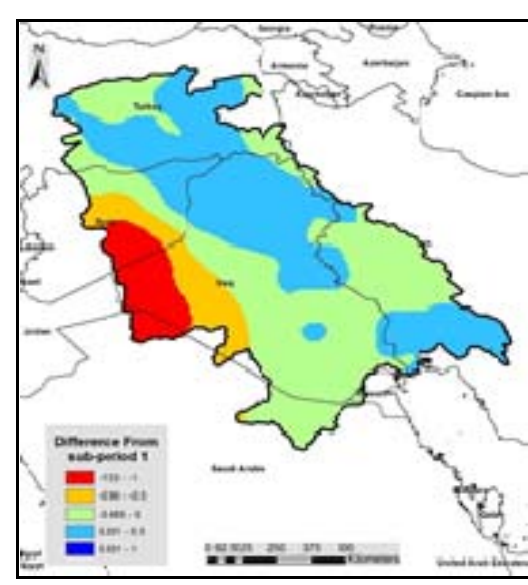

a) 1930-1959

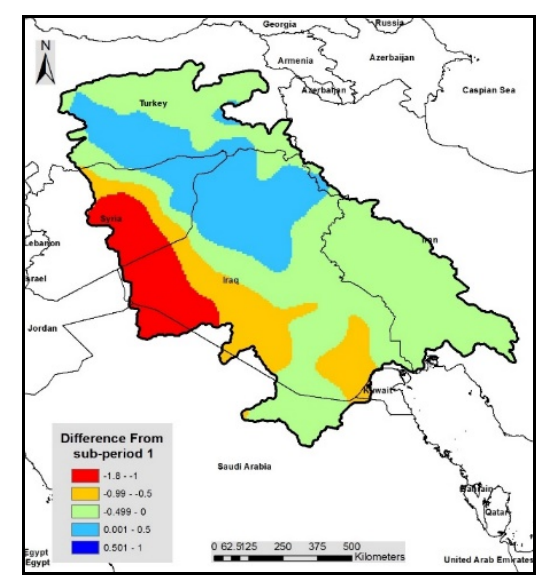

b) $1960-1989$

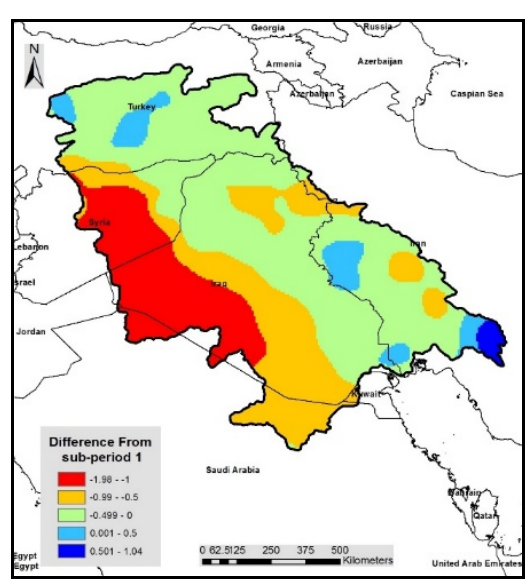

c) $1985-2014$

Fig. 4. Spatial variation of the SPI 12-month anomalies compared to the average of the first sub-period 1900-1929

dominate $78.14 \%$ of the region. Finally, Fig. 4 (c) illustrates the spatial variation of the drought index anomalies for the fourth sub-period. Positive anomalies (up to 1.04 above normal) dominate $6.69 \%$ of the area within the Euphrates-Tigris Rivers basin, whereas negative anomalies (down to 1.98 below normal) dominate $93.31 \%$ of the region.

The probability of occurrence of various categories of wet and dry periods depending on the 12-month timescale of the SPI in Iraq is shown in Tab. 6.

Table 6

Drought classification based on 12-month SPI in Iraq for the four sub-periods

\begin{tabular}{|c|c|c|c|c|c|c|c|c|}
\hline \multirow{2}{*}{ Class } & 1900-1929 & \multirow{2}{*}{$\%$} & 1930-1959 & \multirow{2}{*}{$\%$} & 1960-1989 & \multirow{2}{*}{$\%$} & 1985-2014 & \multirow{2}{*}{$\%$} \\
\hline & No. months & & No. months & & No. months & & No. months & \\
\hline $\begin{array}{c}\text { Extremely } \\
\text { wet }\end{array}$ & 12 & \multirow{3}{*}{18.6} & 12 & \multirow{3}{*}{20.0} & 12 & \multirow{3}{*}{18.3} & 10 & \multirow{3}{*}{4.7} \\
\hline Very wet & 21 & & 25 & & 27 & & 3 & \\
\hline $\begin{array}{c}\text { Moderately } \\
\text { wet }\end{array}$ & 34 & & 35 & & 27 & & 4 & \\
\hline Near normal & 260 & & 244 & & 237 & & 245 & \\
\hline $\begin{array}{c}\text { Moderately } \\
\text { dry }\end{array}$ & 21 & \multirow{3}{*}{6.1} & 29 & \multirow{3}{*}{12.2} & 32 & \multirow{3}{*}{15.8} & 50 & \multirow{3}{*}{27.2} \\
\hline Very dry & 1 & & 14 & & 17 & & 21 & \\
\hline $\begin{array}{c}\text { Extremely } \\
\text { dry }\end{array}$ & 0 & & 1 & & 8 & & 27 & \\
\hline
\end{tabular}

A simple comparison can be made by using SPI of the first sub-period as a benchmark for all other sub-periods. In the second (third) sub-period, $12.22 \%(15.83 \%)$ of the time series revealed dry periods with varying intensities, indicating that drought frequency increased by $100(159) \%$ compared to the first sub-period. And finally, the fourth sub-period revealed $27.22 \%$ dry periods, indicating that drought frequency increased by $345.5 \%$.

It should be noted, however, that the greatest reduction in annual precipitation is observed in most arid western parts of Iraq, where agriculture is mainly irrigated (see Fig. 2 and Fig. 4). So here the impact of reduction of precipitation can be partially compensated. In 
Temperature classification based on z-score in Iraq for the four sub-periods

\begin{tabular}{|c|c|c|c|c|c|c|c|c|}
\hline \multirow{2}{*}{ Class } & 1900-1929 & \multirow{2}{*}{$\%$} & 1930-1959 & \multirow{2}{*}{$\%$} & 1960-1989 & \multirow{2}{*}{$\%$} & 1985-2014 & \multirow{2}{*}{$\%$} \\
\hline & No. months & & No. months & & No. months & & No. months & \\
\hline $\begin{array}{l}\text { Extremely } \\
\text { Cold }\end{array}$ & 6 & \multirow{3}{*}{16.4} & 15 & \multirow{3}{*}{18.9} & 10 & \multirow{3}{*}{18.9} & 4 & \multirow{3}{*}{7.2} \\
\hline Very Cold & 16 & & 15 & & 19 & & 9 & \\
\hline $\begin{array}{c}\text { Moderately } \\
\text { Cold }\end{array}$ & 37 & & 38 & & 46 & & 13 & \\
\hline Near normal & 253 & & 261 & & 237 & & 218 & \\
\hline $\begin{array}{c}\text { Moderately } \\
\text { Hot }\end{array}$ & 29 & \multirow{3}{*}{12.8} & 26 & \multirow{3}{*}{8.3} & 31 & \multirow{3}{*}{15.8} & 54 & \multirow{3}{*}{31.7} \\
\hline Very Hot & 15 & & 4 & & 11 & & 35 & \\
\hline $\begin{array}{c}\text { Extremely } \\
\text { Hot }\end{array}$ & 2 & & 0 & & 2 & & 25 & \\
\hline
\end{tabular}

rain-fed areas in the northern Iraq, there also was a decrease in precipitation, but not so strong as in the west of the country.

The surface air temperature z-score was calculated and analyzed at a regional scale in reference to the mean monthly temperature in Iraq. The probability of occurrence of various categories of relatively cold and hot conditions depending on the z-score in Iraq is shown in Tab. 7. As in the case of precipitation, z-score of the first sub-period can be used as a benchmark for all other sub-periods. Thus, $8.3 \%$ (15.8\%) of the second (third) sub-periods were presented by hot conditions, indicating that it decreased (increased) by $35.16 \%$ $(23.44 \%)$ in the relation to the first sub-period. And finally, during fourth sub-period, the $31.7 \%$ of the time were occupied by hot conditions, $147.7 \%$. Obviously, winter and summer effects of warm and cold weather are different, so that we examined seasonal distribution of the number of months with more colder (warmer) than normal (Tab. 8).

As can be seen from Tab. 8, the greatest number of months with significant excess of normal temperatures ( $>9$ cases) was observed in the last period, from March to September, with a maximum of frequency up to 14 months in July. This actually means the likelihood to observe of high temperatures every third summer. Note that during the winter months, when there is a noticeable decrease in precipitation $(5-6 \mathrm{~mm}$, see Tab. 4), the frequency of the warm events (5-7 cases) was lower than in summer and was balanced by number of cold events $(3-5)$.

\section{Conclusion}

If one combines the results of Sections 2.1-2.5, it turns out that the increase in the frequency of dry months (Tab. 7) and the decrease in winter rainfall (Tab. 4) are accompanied by the moving of hydrological drought borders, from deserts of Syria and west of Iraq to upper and lower Mesopotamia (Fig. 4). Here, in a densely populated valley of the Tigris, the major increase in temperature was observed during last 30-years (Fig. 3 (d)). This increase coincides with the end of the rainy season and the onset of summer. It is evident that the establishment of more hot regional conditions, in general, is accompanied by increased frequency of extremely high summer temperatures (Tab. 8), that indirectly indicate about pos- 
Seasonal distribution of hot and cold events based on z-score

\begin{tabular}{|c|c|c|c|c|c|c|c|c|}
\hline \multirow{2}{*}{ Month } & \multicolumn{4}{|c|}{ No. hot months $(\mathrm{Z} \geq 1)$} & \multicolumn{4}{c|}{ No. cold months $(\mathrm{Z} \leq-1)$} \\
\cline { 2 - 10 } & $1900-29$ & $1930-59$ & $1960-90$ & $1985-2014$ & $1900-29$ & $1930-59$ & $1960-90$ & $1985-2014$ \\
\hline Jan & 4 & 2 & 3 & 5 & 4 & 4 & 6 & 3 \\
\hline Feb & 4 & 2 & 9 & 7 & 6 & 5 & 6 & 4 \\
\hline Mar & 4 & 4 & 4 & 9 & 7 & 7 & 5 & 4 \\
\hline Apr & 3 & 3 & 4 & 10 & 7 & 5 & 6 & 0 \\
\hline May & 3 & 2 & 4 & 13 & 6 & 6 & 6 & 1 \\
\hline Jun & 2 & 0 & 2 & 13 & 7 & 7 & 5 & 1 \\
\hline Jul & 5 & 0 & 3 & 14 & 3 & 10 & 4 & 2 \\
\hline Aug & 2 & 2 & 2 & 12 & 3 & 6 & 8 & 0 \\
\hline Sep & 4 & 3 & 2 & 9 & 3 & 8 & 4 & 0 \\
\hline Oct & 6 & 3 & 2 & 9 & 4 & 3 & 11 & 3 \\
\hline Nov & 5 & 5 & 5 & 7 & 4 & 2 & 7 & 5 \\
\hline Dec & 4 & 4 & 4 & 6 & 5 & 5 & 7 & 3 \\
\hline
\end{tabular}

sible growth heat waves in the main metropolitan areas of Iraq (Basra, Baghdad and Mosul).

Given the decreasing precipitation in arid areas east of Iraq and increase in summer temperatures nearby lowlands, one can speak about the current climatic desertification of Iraq. On the other hand, the assessment of hydrothermal risks, expressed in standardized precipitation index and temperature, said about generally normal hydrological conditions at the headwaters of the Tigris and Euphrates (Fig. 4). This, despite the construction of dams in the upper basins of these rivers, is conducive to the flow of water into Iraq. That, in turn, compensates for the increase in water consumption for irrigation, associated with a decrease in the atmospheric water component and an acceleration of moisture loss by soil evaporation and by vegetation transpiration at higher temperatures. One notable problem of last 30 years (Fig. $4(\mathrm{~d})$ ) is the emergence of some "spots of drought" in the east and north-east of Iraq. Here, in the basin of the left tributaries of the Tigris, apart from irrigated agriculture, rainfed farming and pasture fields are widely practiced.

The results above indicate about significant decrease (increase) of annual precipitation (temperature) occurred during last century in some parts of the Euphrates-Tigris Rivers basin. Slow climatic changes are accompanied by growing numbers of dry months, when rainfall is far below normal, and the increasing frequency of extremely hot months.

It is obvious that the response to climate change will be different both in agricultural and natural landscapes of Iraq and adjacent territories. The evaluation and verification of this response are the subjects of new study and should be useful for national adaptation to climate change.

This paper is distributed under the terms of the Creative Commons Attribution-Non Commercial 3.0 License which permits non-commercial use, reproduction and distribution of the work without further permission provided the original work is properly cited. 


\section{References}

1. Osman Y., AlAnsari N., Abdellatif M., et al. Expected Future Precipitation in Central Iraq Using LARS-WG Stochastic Weather Generator. Engineering. 2014. vol. 6, no. 13. pp. 948-959. DOI: 10.4236/eng.2014.613086.

2. Zakaria S., Alansari N., Knutsson S. Historical and Future Climatic Change Scenarios for Temperature and Rainfall for Iraq. Journal of Civil Engineering and Architecture. USA. 2013. vol. 7, no. 12. pp. 1574-1594.

3. Yazdanpanah H., Eitzinger J., Baldi M. Analysis of the extreme heat events in Iran. International Journal of Climate Change Strategies and Management. 2017. vol. 9, no. 4. pp. 418-432. DOI: 10.1108/IJCCSM-04-2016-0046.

4. Awchi T.A., Kalyana M.M. Meteorological Drought Analysis in Northern Iraq Using SPI and GIS. Sustainable Water Resources Management. 2017. vol. 3, no. 4. pp. 451-463. DOI: 10.1007/s40899-017-0111-x.

5. Belayneh A., Adamowski J. Standard Precipitation Index Drought Forecasting Using Neural Networks, Wavelet Neural Networks, and Support Vector Regression. Applied Computational Intelligence and Soft Computing. 2012. vol. 2012. pp. 1-13. DOI: $10.1155 / 2012 / 794061$.

6. Dahal P., Shrestha N.S., Shrestha M.L., et al. Drought Risk Assessment in Central Nepal: Temporal and Spatial Analysis. Natural Hazards. 2016. vol. 80, no. 3. pp. 1913-1932. DOI: $10.1007 / \mathrm{s} 11069-015-2055-5$.

7. Palmer W.C. Meteorological Drought. U.S. Department of Commerce Weather Bureau. Washington DC. 1965.

8. Mckee T.B., Doesken N.J., Kleist J. The Relationship of Drought Frequency and Duration to Time Scales. AMS 8th Conference on Applied Climatology (Anaheim, January, 17-22, 1993). 1993. pp. 179-184.

9. Vicente S.M., Beguería S., López J.I. A Multiscalar Drought Index Sensitive to Global Warming: The Standardized Precipitation Evapotranspiration Index. Journal of Climate. 2010. vol. 23, no. 7. pp. 1696-1718. DOI: 10.1175/2009JCLI2909.1

10. Byun H.R., Wilhite D.A. Objective Quantification of Drought Severity and Duration. Journal of Climate. 1999. vol. 12, no. 9. pp. 2747-2756. DOI: 10.1175/15200442(1999)012<2747:OQODSA $>2.0 . \mathrm{CO} ; 2$.

11. Bloomfield J.P., Marchant B.P. Analysis of Groundwater Drought Building on the Standardised Precipitation Index Approach. Hydrology and Earth System Sciences. 2013. vol. 17, no. 12. pp. 4769-4787. DOI: 10.5194/hess-17-4769-2013.

12. Matthews T., Mullan D., Wilby R.L., et al. Past and future climate change in the context of memorable seasonal extremes. Climate Risk Management. 2016. vol. 11. pp. 3752. DOI: $10.1016 /$ j.crm.2016.01.004.

13. El-Fadel M., El Sayegh Y., Ibrahim A.A., et al. The Euphrates Tigris Basin: a Case Study in Surface Water Conflict Resolution. Journal of Natural Resources and Life Sciences Education. 2002. vol. 31. pp. 99-110.

14. UN-ESCWA, BGR (United Nations Economic and Social Commission for Western Asia; Bundesanstalt für Geowissenschaften und Rohstoffe), Inventory of Shared Water Resources in Western Asia. 2013. 
15. Issa I.E., AlAnsari N.A., Sherwany G., et al. Expected Future of Water Resources within Tigris Euphrates Rivers Basin, Iraq. Journal of Water Resource and Protection. 2014. vol. 6. pp. 421-432. DOI: 10.4236/jwarp.2014.65042.

16. Abd-El-Mooty M., Kansoh R., Abdulhadi A. Challenges of Water Resources in Iraq. Hydrology Current Research. 2016. vol. 7, no. 4. pp. 1-8. DOI: 10.4172/2157-7587.1000260.

17. Ministry of Planning. Central Statistical Organization, Annual Statistical Abstract 20142016. Baghdad. Iraq. 2016.

18. Food and Agriculture Organization of the United Nations (FAO), IRAQ Agriculture Damage and Loss Needs Assessment, 2017.

19. Ministry of Agriculture. Annual Agricultural Statistical Data 2014. Baghdad. Iraq. 2014.

20. AL-Timimi Y.K., AL-Jiboori M.H. Assessment of Spatial and Temporal Drought in Iraq during the Period 1980-2010. International Journal of Energy and Environment (IJEE). 2013. vol. 2, no. 4. pp. 291-302.

21. Bilal D.A., Al-Jumaily K.J., Habbib E.A. Air Temperature Trends in Baghdad, Iraq for the Period 1941-2000. International Journal of Scientific and Research Publications. 2013. vol. 3, no. 9. pp. 1-5.

22. Shubbar R.M., Salman H.H., Lee D.I. Characteristics of Climate Variation Indices in Iraq using a Statistical Factor Analysis. International Journal of Climatology. 2017. vol. 37, no. 2. pp. 918-927. DOI: $10.1002 /$ joc.4749.

23. Omar M.A., Agha M., Şarlak N. Spatial and Temporal Analysis of Drought in Iraq Using the Standardized Precipitation Index. Journal of Applied Physics (IOSR-JAP), 2007. vol. 8, no. 6. pp. 19-25. DOI: 10.9790/4861-0806051925.

24. Food and Agriculture Organization United Nations (FAO). Euphrates Tigris River Basin. 2009.

25. Özdoğan M. Climate Change Impacts on Snow Water Availability in the Euphrates Tigris basin. Hydrology and Earth System Sciences. 2011. vol. 15, no. 9. pp. 2789-2803. DOI: $10.5194 /$ hess-15-2789-2011.

26. Yıldız D. Natural Diminishing Trend of the Tigris and Euphrates Streamflows is Alarming for the Middle East Future. World Scientific News. 2016. vol. 47, no. 2. pp. 279-297.

27. AlAnsari N., Knutsson S. Toward Prudent Management of Water Resources in Iraq. Journal of Advanced Science and Engineering Research. 2011. vol. 1. pp. 53-67.

28. Al-Ansari N.A. Management of Water Resources in Iraq: Perspectives and Prognoses. Engineering. 2013. vol. 5, no. 8. pp. 667-684. DOI: 10.4236/eng.2013.58080.

29. Willmott C.J., Matsuura K. Terrestrial Air Temperature and Precipitation: Monthly and Annual Time Series (1950-1999). Version 4.01. University of Delaware. Department of Geography. 2015. Available at: http://climate.geog.udel.edu/ climate/html_pages/ Global2014/README.GlobalTsT2014.html.

30. Behrangi A., Nguyen H., Granger S. Probabilistic Seasonal Prediction of Meteorological Drought using the Bootstrap and Multivariate Information. Journal of Applied Meteorology and Climatology. 2015. vol. 54, no. 7. pp. 1510-1522. DOI: 10.1175/JAMC-D-140162.1 .

31. Shah R., Bharadiya N., Manekar V. Drought Index Computation Using Standardized Precipitation Index (SPI) Method For Surat District, Gujarat. International Conference on Water Resources, Coastal and Ocean Engineering (ICWRCOE). 2015. vol. 4. pp. 1243-1249. DOI: 10.1016/j.aqpro.2015.02.162. 


\title{
ПРЕДВАРИТЕЛЬНАЯ ОЦЕНКА ГИДРОТЕРМАЛЬНЫХ РИСКОВ В БАССЕЙНЕ ЕВФРАТА И ТИГРА: ЗАСУХИ В ИРАКЕ
}

\author{
(C) 2018 А.С. Алхумайма, С.М. Абдуллаев \\ Южно-Уральский государственный университет \\ (454080 Челябинск, пр. им. В.И. Ленина, д. 76) \\ E-mail: engineer_alisubhi@yahoo.com,abdullaevsm@susu.ru
}

Поступила в редакцию: 27.03.2018

В работе исследованы пространственно-временные аномалии месячных температур и осадков, в бассейне рек Евфрат-Тигр, а также изменение частоты засух в республике Ирак. Весь ряд данных с 1900 по 2014 год были разделен на четыре тридцатилетних интервала (1900-1929, 1930-1950, 1960-1989, 1985-2014), для которых вычислены средние значения температуры и сумм осадков, индексы засушливости и другие характеристики. Анализ показал, что среднее количество осадков в Ираке за четыре интервала последовательно уменьшалось с 218,5, 202,1, 196,4 до 174,9 мм, при среднем значении за весь период 198 мм. Таким образом, примерно за 100 лет наблюдается 20 \% уменьшение осадков. Среднегодовая температура в последний тридцатилетний период напротив, выросла по сравнению с началом 20 века на 0,76 ${ }^{\circ} \mathrm{C}$, или на $3,45 \%$. При этом частота засушливых (жарких) месяцев в Ираке увеличилась на $345 \%$ (148 \%) за столетие. Отмечено, что увеличение засушливости, в большей мере, наблюдается в зонах орошаемого земледелия западного Ирака. На севере и северо-востоке страны, где сосредоточены районы богарного земледелия и пастбищного животноводства, рост частоты засушливых условий, более умеренный, чем на западе Ирака. Сделан вывод о текущем климатическом опустынивании Ирака и его возможных следствиях.

Ключевые слова: бассейн рек Евфрат-Тигр, Ирак, температура, осадки, изменение климата, zоценка, стандартизованный индекс осадков.

\section{ОБРАЗЕЦ ЦИТИРОВАНИЯ}

Alhumaima A.S. Abdullaev S.M. Preliminary Assessment of Hydrothermal Risks in the Euphrates-Tigris Basin: Droughts in Iraq // Вестник ЮУрГУ. Серия: Вычислительная математика и информатика. 2018. Т. 7, № 4. С. 41-58. DOI: 10.14529/cmse180403.

\section{Литература}

1. Osman Y., AlAnsari N., Abdellatif M., et al. Expected Future Precipitation in Central Iraq Using LARS-WG Stochastic Weather Generator // Engineering. 2014. Vol. 6, No. 13. P. 948-959. DOI: 10.4236/eng.2014.613086.

2. Zakaria S., Alansari N., Knutsson S. Historical and Future Climatic Change Scenarios for Temperature and Rainfall for Iraq // Journal of Civil Engineering and Architecture. USA. 2013. Vol. 7, No. 12. P. 1574-1594.

3. Yazdanpanah H., Eitzinger J., Baldi M. Analysis of the extreme heat events in Iran // International Journal of Climate Change Strategies and Management. 2017. Vol. 9, No. 4. P. 418-432. DOI: 10.1108/IJCCSM-04-2016-0046.

4. Awchi T.A., Kalyana M.M. Meteorological Drought Analysis in Northern Iraq Using SPI and GIS // Sustainable Water Resources Management. 2017. Vol. 3, No. 4. P. 451-463. DOI: 10.1007/s40899-017-0111-x.

5. Belayneh A., Adamowski J. Standard Precipitation Index Drought Forecasting Using Neural Networks, Wavelet Neural Networks, and Support Vector Regression // Applied 
Computational Intelligence and Soft Computing. 2012. Vol. 2012. P. 1-13. DOI: $10.1155 / 2012 / 794061$.

6. Dahal P., Shrestha N.S., Shrestha M.L., et al. Drought Risk Assessment in Central Nepal: Temporal and Spatial Analysis // Natural Hazards. 2016. Vol. 80, No. 3. P. 19131932. DOI: $10.1007 / \mathrm{s} 11069-015-2055-5$.

7. Palmer W.C. Meteorological Drought. U.S. Department of Commerce Weather Bureau. Washington DC. 1965.

8. Mckee T.B., Doesken N.J., Kleist J. The Relationship of Drought Frequency and Duration to Time Scales // AMS 8th Conference on Applied Climatology (Anaheim, January, 17-22, 1993). 1993. P. 179-184.

9. Vicente S.M., Beguería S., López J.I. A Multiscalar Drought Index Sensitive to Global Warming: The Standardized Precipitation Evapotranspiration Index // Journal of Climate. 2010. Vol. 23, No. 7. P. 1696-1718. DOI: 10.1175/2009JCLI2909.1.

10. Byun H.R., Wilhite D.A. Objective Quantification of Drought Severity and Duration // Journal of Climate. 1999. Vol. 12, No. 9. P. 2747-2756. DOI: 10.1175/15200442(1999)012<2747:OQODSA $>2.0$.CO $; 2$.

11. Bloomfield J.P., Marchant B.P. Analysis of Groundwater Drought Building on the Standardised Precipitation Index Approach // Hydrology and Earth System Sciences. 2013. Vol. 17, No. 12. P. 4769-4787. DOI: 10.5194/hess-17-4769-2013.

12. Matthews T., Mullan D., Wilby R.L., et al. Past and future climate change in the context of memorable seasonal extremes // Climate Risk Management. 2016. Vol. 11. P. 3752. DOI: $10.1016 /$ j.crm.2016.01.004.

13. El-Fadel M., El Sayegh Y., Ibrahim A.A., et al. The Euphrates Tigris Basin: a Case Study in Surface Water Conflict Resolution // Journal of Natural Resources and Life Sciences Education. 2002. Vol. 31. P. 99-110.

14. UN-ESCWA, BGR (United Nations Economic and Social Commission for Western Asia; Bundesanstalt für Geowissenschaften und Rohstoffe), Inventory of Shared Water Resources in Western Asia. 2013.

15. Issa I.E., AlAnsari N.A., Sherwany G., et al. Expected Future of Water Resources within Tigris Euphrates Rivers Basin, Iraq // Journal of Water Resource and Protection. 2014. Vol. 6. P. 421-432. DOI: 10.4236/jwarp.2014.65042.

16. Abd-El-Mooty M., Kansoh R., Abdulhadi A. Challenges of Water Resources in Iraq // Hydrology Current Research. 2016. Vol. 7, No. 4. P. 1-8. DOI: 10.4172/21577587.1000260.

17. Ministry of Planning. Central Statistical Organization, Annual Statistical Abstract 20142016. Baghdad. Iraq. 2016.

18. Food and Agriculture Organization of the United Nations (FAO), IRAQ Agriculture Damage and Loss Needs Assessment, 2017.

19. Ministry of Agriculture. Annual Agricultural Statistical Data 2014. Baghdad. Iraq. 2014.

20. AL-Timimi Y.K., AL-Jiboori M.H. Assessment of Spatial and Temporal Drought in Iraq during the Period 1980-2010 // International Journal of Energy and Environment (IJEE). 2013. Vol. 2, No. 4. P. 291-302.

21. Bilal D.A., Al-Jumaily K.J., Habbib E.A. Air Temperature Trends in Baghdad, Iraq for the Period 1941-2000 // International Journal of Scientific and Research Publications. 2013. Vol. 3, No. 9. P. 1-5. 
22. Shubbar R.M., Salman H.H., Lee D.I. Characteristics of Climate Variation Indices in Iraq using a Statistical Factor Analysis // International Journal of Climatology. 2017. Vol. 37, No. 2. P. 918-927. DOI: 10.1002/joc.4749.

23. Omar M.A., Agha M., Şarlak N. Spatial and Temporal Analysis of Drought in Iraq Using the Standardized Precipitation Index // Journal of Applied Physics (IOSR-JAP). 2007. Vol. 8, No. 6. P. 19-25. DOI: 10.9790/4861-0806051925.

24. Food and Agriculture Organization United Nations (FAO). Euphrates Tigris River Basin. 2009.

25. Özdoğan M. Climate Change Impacts on Snow Water Availability in the Euphrates Tigris basin // Hydrology and Earth System Sciences. 2011. Vol. 15, No. 9. P. 2789-2803. DOI: $10.5194 /$ hess-15-2789-2011.

26. Yıldız D. Natural Diminishing Trend of the Tigris and Euphrates Streamflows is Alarming for the Middle East Future // World Scientific News. 2016. Vol. 47, No. 2. P. 279297.

27. AlAnsari N., Knutsson S. Toward Prudent Management of Water Resources in Iraq // Journal of Advanced Science and Engineering Research. 2011. Vol. 1. P. 53-67.

28. Al-Ansari N.A. Management of Water Resources in Iraq: Perspectives and Prognoses // Engineering. 2013. Vol. 5, No. 8. P. 667-684. DOI: 10.4236/eng.2013.58080.

29. Willmott C.J., Matsuura K. Terrestrial Air Temperature and Precipitation: Monthly and Annual Time Series (1950-1999). Version 4.01. University of Delaware. Department of Geography. 2015. Available at: http://climate.geog.udel.edu/ climate/html_pages/ Global2014/README.GlobalTsT2014.html.

30. Behrangi A., Nguyen H., Granger S. Probabilistic Seasonal Prediction of Meteorological Drought using the Bootstrap and Multivariate Information // Journal of Applied Meteorology and Climatology. 2015. Vol. 54, No. 7. P. 1510-1522. DOI: 10.1175/JAMC-D-140162.1.

31. Shah R., Bharadiya N., Manekar V. Drought Index Computation Using Standardized Precipitation Index (SPI) Method For Surat District, Gujarat // International Conference on Water Resources, Coastal and Ocean Engineering (ICWRCOE). 2015. Vol. 4. P. 1243-1249. DOI: 10.1016/j.aqpro.2015.02.162.

Алхумайма Али Субхи, аспирант, Южно-Уральский государственный университет (национальный исследовательский университет) (Челябинск, Российская Федерация)

Абдуллаев Санжар Муталович, доктор географических наук, профессор, кафедра системного программирования, Южно-Уральский государственный университет (национальный исследовательский университет) (Челябинск, Российская Федерация) 